\title{
Behandling av opioid abstinens
}

\author{
Opioid abstinens kan gi dramatiske symptomer, men er sjelden eller \\ aldri livstruende. Forskrivning av morfinstoffer kan opprettholde \\ rusvanen og derfor forlenge vanskene, men lindrer også reelle plager.
}

Se også kunnskapsprøve på www.tidsskriftet.no/quiz

Morfinreseptorene har viktige regulerende funksjoner i organismen og finstemmes av endorfiner og enkefaliner. Opioider er en fellesbetegnelse for morfinstoffer som stammer fra opiumsvalmuen og for dem som er syntetisk produsert. Opioidene kan stimulere reseptorene utover den naturlige reguleringen. Det er vanlig å bruke begrepene morfinvirkning om stimulering av reseptor og abstinens om underfunksjonen som følger. Reseptorene har imidlertid mange og ulike regulerende funksjoner i kroppen. Enkelte av disse assosieres ikke naturlig med betegnelsen morfinvirkning. Den endrede funksjonen som følger stimuleringen, kan ha langvarige virkninger, delvis forankret $i$ endret gentranskripsjon. Det er derfor mer hensiktsmessig å skille mellom den direkte effekten som viser seg når opioidene stimulerer reseptor og den indirekte som kommer frem når stimuleringen reduseres eller opphører.

I de dopaminerge motivasjonsbanene er den direkte effekten stimulerende og gir velvære og opplevelse av meningsfullhet. Den indirekte domineres av nedstemthet med dysfori og opplevelse av meningsløshet og tiltaksvansker. I noradrenerge baner er den direkte virkningen dempende. Den direkte virkningen er derfor nedsatt tonus i hele det sympatiske nervesystemet. Den indirekte er motsatt rettet. Morfinstoffene har dessuten en dempende virkning på hypothalamushypofyse-binyre-samspillet og senker derfor adrenalin- og kortisolspeilet. Den indirekte virkningen er en hyperadrenerg tilstand med høy sympatikustonus og høy stimulering av binyrene.

Abstinenssymptomer stammer fra slik nedsatt aktivitet i dopaminregulerte baner og oppregulert funksjon i noradrenerge baner. Funksjonsendringene har både kortvarige og langvarige elementer. De kortvarige er knyttet til hyperadrenerge endringer sammen med fortvilelse knyttet til hypofunksjon i motivasjonsbanene (e-tab 1). Disse virkningene er relativt kortvarige. De typiske abstinenssymptomene klinger derfor av i løpet av 1-3 uker. Det er imidlertid også endringer betinget av forandringer i gentranskripsjon.
Dette kan gi langvarige forstyrrelser både i motivasjonsforhold og i stressregulering og derfor tendens til tilbakefall. I denne artikkelen behandles bare de kortvarige forstyrrelsene vi oftest forbinder med abstinensreaksjoner.

\section{Materiale og metode}

Fremstillingen er basert på internasjonale kunnskapsoppsummeringer (1-8) og på forfatternes kliniske erfaringer. Særlig vekt er lagt på engelske retningslinjer som er spesielt utviklet på grunnlag av omfattende kunnskapsoppsummeringer fra National Institute for Health and Clinical Excellence (7).

\section{Symptomer og farlighet}

Tabell 1 viser en oversikt over symptomene inndelt etter klinisk betydning. En lett abstinens viser seg ved moderate tegn på reversering av morfinstoffenes perifere virkninger. De mest markerte omfatter generelle symptomer med angst, alvorlige gastrointestinale vansker og symptomer fra muskel- og skjelettsystemet. Dersom pasienten er disponert for det, kan det utløses stressbetingede psykotiske reaksjoner og dissosiasjon. Tiden fra siste tilførsel til abstinenssymptomene melder seg, varierer med type morfinstoff, mengden som er brukt og metaboliseringshastigheten hos brukeren. Opioider med kort halveringstid, som heroin, kan gi abstinensvansker allerede etter 4-6 timer. Metadon har lang halveringstid (oftest 24-36 timer). Reaksjonene kan begynne etter vel ett døgn. Enkelte medikamenter har farmakokinetiske interaksjoner, slik at plagene kan komme både raskere og senere. Langsom nedbryting gir mindre dramatiske symptomer, men til gjengjeld varer de lenger.

\section{Behandlingsalternativer}

I prinsippet er det fire behandlingsalternativer: brå avvenning (cold turkey), symptomorientert lindrende behandling, nedtrapping med minskende doseringer av et opioid og avvenning under dyp sedasjon. Tabell 2 viser en oversikt. Brukere med kortvarig eller svingende forbruk kan behandles vellykket uten medikamentelle midler under forutsetning av sterk nok støtte. De viktigste symptomlindrende midlene er presynaptiske adrenerge agonister som demper hyperadrenerge tilstander. Flere kontrollerte randomiserte studier viser at dette gir tilnærmet like god symptomlindring som bruk av en opioidagonist (2), men lengselen etter rusmidlet svekkes lite og nokså mange avbryter behandlingen (7). Den vanligste anbefalingen er derfor i dag nedtrapping eller vedlikeholdsbehandling. De som er best utforsket, er metadon og buprenorfin $(1,3,7)$.

Metadon er som heroin en fullagonist og kan lindre abstinensplager fullt ut $(1,7)$. Metadon har imidlertid langsom nedbryting, slik at man kan få en additiv virkning som blant annet kan gi respirasjonsstans. Avvenning med metadon bør derfor forbeholdes medisinske institusjoner. Det er vanlig å begynne med 30-50 mg metadonløsning. Om nødvendig kan man gi ytterligere $10 \mathrm{mg} \mathrm{1-2}$ ganger til i løpet av døgnet. Etter stabilisering på dette nivået reduseres doseringen gradvis. Det finnes to ulike anbefalinger, langsom og rask avvenning (7). Ved langsom avvenning reduseres doseringen oftest med ukentlige reduksjoner. Innenfor institusjon er det mer vanlig å redusere over 1-3 uker, for eksempel med 5-10 mg daglig eller annenhver dag. Tempoet kan justeres i forhold til pasientens symptomer. Det er ikke sikkert kunnskapsgrunnlag for at det er forskjell i prognose mellom alternativene, men langsom avvenning gir mindre plager.

Buprenorfin er en såkalt partiell opioidagonist og har en øvre dose-respons-grense. Dette gjør preparatene mindre farlige $(3,6$, 7). De brukes oftest som resoribletter som er velegnet til oppløsning. De blir derfor ikke sjelden misbrukt i injeksjonsform. Det er nå kommet et buprenorfinplaster med tre styrker. Det kraftigste frigjør omtrent $0,5 \mathrm{mg}$ i døgnet. Buprenorfin blokkerer morfinreseptorene uten å stimulere dem så intenst som for eksempel heroin gjør, og kan derfor utløse

\section{Hovedbudskap}

- Medikamentell behandling skal bygge på diagnostisk vurdering av opioid avhengighet

- Nedtrapping med buprenorfin og metadon har sterkest empirisk støtte

- Utenfor sykehus bør symptomatisk behandling være førstevalg 
abstinensreaksjoner hos aktive heroinbrukere. Det bør derfor ha gått 6-8 timer etter siste heroininntak. Det er vanlig å begynne med 2-4 mg som økes til $8 \mathrm{mg}$, eventuelt $12 \mathrm{mg}$ i løpet av 2-3 døgn. Dette reduseres over en uke til $2 \mathrm{mg}(3,7)$. Pasienten har da kommet ned til et så lavt doseringsnivå at man eventuelt kan gå over til behandling med buprenorfinplaster som er enklere å administrere. Det finnes relativt omfattende litteratur om avvenning med buprenorfin $(3,6,7)$. I England og Australia er det økende vekt på å bruke dette i kort nedtrapping (1-3 uker).

Avvenning i lett eller dyp sedasjon, eventuelt i narkose er tilgjengelig i land som England og Spania. Pasientene får først sedasjon eller narkose så de ikke skal kjenne abstinensplager, deretter en antagonist, ofte naltrekson. Dette blokkerer my-reseptorene for opioid påvirkning. Nevroadaptasjonen vil derfor reverseres raskere $(4,5)$. Ved dyp sedasjon eller narkose kan pasienten våkne opp med gjennomført avvenning. Enkelte pasienter og pårørende etterspør dette tilbudet, men langtidsprognosen blir ikke endret, og behandlingen er ikke helt ufarlig (7). I England frarådes avvenning i narkose. I Norge anser vi behandling under dyp sedasjon som lite aktuelt, med mulig unntak for pasienter som har utviklet angstreaksjoner knyttet til avvenningen.

\section{Lokalisering av behandlingen}

I prinsippet kan opioid avvenning skje i hjemmet, i poliklinisk kontakt eller i døgninstitusjon. Avvenning som omfatter forskrivning av opioider forutsetter at legen har avtalt langsiktig oppfølging av pasienten $(7,9)$.

Utleveringsbestemmelsene begrenser bruken av metadon til institusjoner. Alle leger har imidlertid rett til å behandle opioid abstinens med andre opioider, også buprenorfin. Behandlingen skal ha avtalt formål og tidsramme og bør skje i samarbeid med spesialisthelsetjenesten. Langsom nedtrapping er bare aktuelt for medikamentavhengige som har vist samarbeidsevne innenfor en fast legekontakt. Pasienten bør ikke selv oppbevare medikamentet. Mange mislykkes likevel uten et skjermet miljø. Helsetilsynets rundskriv IK-2755 gir retningslinjene for dette (9).

\section{Råd for behandling}

Det kan være mange grunner til at pasienter søker lege for behandling av opioid abstinens. Forskrivning kan øke tilvenningen og forlenge avhengighetstilstanden. Avvenning alene påvirker dessuten ikke langtidsprognosen vesentlig $(7,10)$. En avvent pasient er dessuten mer sårbar for overdosering. Dette gjør at man for eksempel i England advarer mot avvenning dersom denne ikke er fulgt av langvarig oppfølging (7).

Legen skal vurdere graden av avhengighet, helsetilstand og mulige kontraindikasjoner før valg av tiltak. Rusanamnese og vur-

Tabell 2 Behandlingsalternativer ved opioid abstinens

$\begin{array}{ll}\text { Metode } & \text { Tiltak } \\ \text { Brå avvenning } & \text { Omsorg, støtte, skjermet miljø }\end{array}$

lcold turkey)

Symptomorientert Antiadrenerge medikamenter avvenning med (klonidin, lofexidin)

lindrende medika- Antihistaminer som sedativer og menter hypnotika

Antidepressiver med sederende virkning

(trimipramin, mianserin, mirtazapin)

Antiemetika (metoklopramid,

ondansetron)

Antidiarroika (loperamid)

Opioid nedtrapping Minskende dosering av opioidagonist (buprenorfin, metadon)

Avvenning i seda- Brå avvenning med antagonist under sjon eller narkose dekke av dyp sedasjon med benzodiazepiner og antiemetiske og antiadrenerge midler

Målgruppe

Pasienter uten eller med liten grad av nevroadaptasjon. Yngre pasienter med kortvarig rusmiddelbruk og god sosial situasjon

Pasienter med liten til moderat grad av nevroadaptasjon. Pasienter i behandling utenfor spesialinstitusjoner

dering av psykososial situasjon er derfor nødvendig $(7,9)$. ICD-10-systemet har seks kriterier for opioid avhengighetssyndrom: 1. Sterkt ønske om å bruke, 2. Eksempler på kontrollsvikt (klarer ikke regulere bruken), 3. Abstinenssymptomer (tab 1), 4. Toleranseutvikling (må ha mer for å oppnå samme effekt), 5. Dominerende bruk av tid og ressurser, 6. Bruk på tross av erkjente negative følger. Diagnosen avhengighetssyndrom forutsetter at minst tre kriterier er tilfredsstilt.

Dersom det ikke foreligger reell avhengighet, er det kontraindisert å forskrive opioide agonister $(7,9)$. Psykososiale støttetiltak, eventuelt med bruk av støttende medikasjon bør velges. Dersom det foreligger avhengighet, bør legen velge mellom avvenning, stabilisering for diagnostisk avklaring eller legemiddelassistert rehabilitering (LAR) (9). All behandling skal ha et langsiktig perspektiv basert på biologiske, psykologiske og sosiale tiltak.

Det kan være nødvendig å stabilisere pasienten med et opioid for å kunne velge veien videre. Slik stabilisering skal være kortvarig på lavest mulige doseringsnivå. Mange har en moderat grad av nevroadaptasjon. Buprenorfinplaster kan mildne symptomer og er dessuten ufarlig og enkelt å styre. Det advares mot samtidig forskrivning av opioider og benzodiazepinpreparater. Søkes det legemiddelassistert rehabilitering, skal det ansvarlige senteret etter pasientrettighetsloven ha vurdert søknaden innen 30 virkedager. Uten godkjent søknad kan legen ikke starte langtidsbehandling. «Ventekvote» er i strid med retningslinjene, men etter at søknaden er innvilget, kan legen inngå avtale med senteret om eventuell medikasjon (9).

\section{Shahram Shaygani}

Klinikk for rus og avhengighet

Akuttenheten Ullevål

Aker universitetssykehus

\section{Helge Waal}

helge.waal@medisin.uio.no

Institutt for psykiatri

Nasjonalt senter for rus- og

avhengighetsforskning (SERAF)

Universitetet i Oslo

Kirkeveien 166

0407 Oslo

Oppgitte interessekonflikter: Ingen

e-tab 1 finnes i artikkelen på www.tidsskriftet.no

\section{Litteratur}

1. Amato L, Davoli M, Minozzi S et al. Methadone at tapered doses for the management of opioid withdrawal. Cochrane Database Syst Rev 2005; nr 3: CD003409

2. Gowing L, Ali R, White J. Opioid antagonists and adrenergic agonists for the management of opioid withdrawal. Cochrane Database Syst Rev 2002: nr 2: CD002021.

3. Gowing L, Ali R, White J. Buprenorphine for the management of opioid withdrawal. Cochrane Database Syst Rev 2006: nr 2: CD002025.

4. Gowing L, Ali R, White J. Opioid antagonists under heavy sedation or anaesthesia for opioid withdrawal. Cochrane Database Syst Rev 2006; nr 2 CD002022

5. Gowing L, Ali R, White J. Opioid antagonists with minimal sedation for opioid withdrawal. Cochrane

6. Lintzeris N, Clark N, Mühleisen P et al. National Clinical Guidelines and procedures for the use of buprenorphine in the treatment of heroin dependence. National Drug Strategy. Canberra: Department of Health and Aged Care, 2001.

7. National Institute of Health and Clinical Excellence. NICE clinical guideline 52. Drug misuse: opioid detoxification. Rapport nr. 52. London: National Institute of Health and Clinical Excellence, 2007.

8. Statens beredning för medicinsk utvärdering. Behandling av alkohol- och narkotikaproblem: en evidensbaserad kunnskapssammanställning Stockholm: SBU, 2001.

9. Vanedannende legemidler - forskrivning og forsvarlighet. IK 2755. Oslo: Statens helsetilsyn, 2001.

10. Gowing LR, Ali RL. The place of detoxification in treatment of opioid dependence. Curr Opin PsychiDatabase Syst Rev 2006; nr 1: CD002021. atry 2006; 19: $266-70$ 